\title{
Kemahiran Insaniah Pelajar Prasiswazah: Analisis Perbezaan Jantina
}

\author{
Hazilah Mohd Amin ${ }^{a *}$, Johari Jaafar ${ }^{b}$, Zaihosnita Hood ${ }^{a}$, Saidah Saad ${ }^{a}$, Hamizah Mohd Amin ${ }^{a}$ \\ ${ }^{a}$ Fakulti Teknologi dan Sains Maklumat, Universiti Kebangsaan Malaysia, 43600, Bangi, Selangor, Malaysia \\ ${ }^{b}$ Sekolah Menengah Kebangsaan Dato' Sheikh Ahmad, 70400 Seremban, Negeri Sembilan
}

*Corresponding author: hazilahm@gmail.com

\section{Article history}

Received :7 November 2012 Received in revised form : 1 December 2012

Accepted : 15 February 2013

\begin{abstract}
Soft skills are important in virtually every profession in the workplace. Therefore, when evaluating employees, organizations will look for graduates with soft skills in addition to technical skills. However, in-depth studies on the extent these skills have been acquired by students in local higher education institutions have not been fully explored. Thus, this paper discusses this issue based on a study on 165 students' soft skills assessment forms completed by industry supervisors during 2011 industrial training. Data was analyzed descriptively and inferentially using t-test. Findings of this study found that generally, teamwork skills, professionalism, social responsibility, and ICT skills were generally at high level. However, communication and problem solving skills were found to be at a moderate level. The study also found that skills in using ICT hardware, accept criticism, respect for others' views, and time management skills were effective differentiators in explaining genders differences. The research has brought meaningful implications for undergraduate students, employers and policy makers.
\end{abstract}

Keywords: Soft skills; generic; employability; competency; employer; industrial training; gender

\begin{abstract}
Abstrak
Kemahiran Insaniah adalah penting dalam hampir setiap bidang pekerjaan. Oleh itu, calon pekerja yang dicari oleh organisasi adalah graduan yang mempunyai kemahiran insaniah di samping kemahiran teknikal. Walau bagaimanapun, kajian tentang sejauh mana kemahiran ini dimiliki oleh pelajar institusi pengajian tinggi tempatan masih belum banyak dilakukan. Justeru, kertas kerja ini cuba mengupas isu tersebut berdasarkan kajian ke atas 165 borang penilaian kemahiran insaniah pelajar latihan industri 2011 yang diisi oleh penyelia syarikat. Data dianalisis secara deskriptif dan inferensi menggunakan ujian-t. Dapatan kajian mendapati kemahiran kerja berpasukan, profesionalisme, tanggungjawab sosial, dan kemahiran ICT pelajar adalah tinggi. Namun kemahiran komunikasi dan penyelesaian masalah didapati berada pada tahap sederhana. Seterusnya, dapatan kajian mendapati kemahiran mengguna perkakasan ICT, menerima teguran, menghormati pandangan dan kemahiran mengurus masa menjadi pembeza efektif dalam menerangkan perbezaan jantina. Kajian ini memberi implikasi yang bermakna kepada pelajar prasiswazah, majikan dan pembuat dasar.
\end{abstract}

Kata kunci: Kemahiran insaniah; generik; kebolehpasaran; kompetensi; majikan; latihan industri; jantina

\subsection{PENGENALAN}

Tingkat kebolehpasaran seorang graduan bukan sahaja bergantung pada pencapaian akademik tetapi bergantung kepada kemahiran insaniah dan kemahiran praktikal (Beard, 2007; Mariana, 2008; Yassin, 2008; Mohamad Sattar Rasul, et al., 2009; Nik Azma, 2011). Majikan melihat bahawa nilai atau kualiti individu yang dimiliki pekerja sangat mempengaruhi keharmonian di tempat kerja dan membantu pekerja dalam menghadapi setiap perubahan yang berlaku (Brown, 2004; Raybould \& Sheedy, 2005; Syed Hussain, 2005; Shahran, 2005; Cox \& King, 2006). Justeru kemahiran insaniah adalah satu aspek kompetensi pekerjaan yang harus dimiliki oleh setiap pekerja untuk membolehkan mereka menjadi seorang pekerja yang berketerampilan dan berkeupayaan tinggi dalam dunia pekerjaan yang diceburi.
Masalah pengangguran di kalangan graduan universiti sering dikaitkan dengan isu kekurangan dan kelemahan graduan yang dikeluarkan oleh institusi pengajian tinggi. Rungutan daripada majikan di Malaysia adalah graduan kurang menguasai kemahiran insaniah (Nurita, et al. 2007; Hassan, et al. 2007; Azami Zaharim, et al. 2009). Ini dapat dilihat dari berita yang terpampang di dada akhbar hampir setiap hari mengenai graduan yang kurang kompeten khususnya dalam kemahiran insaniah (Rohaila Yusof, et al. 2007).

Rohaila Yusof, et al. (2007) mengenal pasti antara punca penyumbang graduan jurusan perniagaan menghadapi kesukaran dalam mendapat pekerjaan adalah kerana kekurangan kemahiran insaniah. Berdasarkan kajian oleh Azami Zaharim, et al. (2009) ke atas 30 majikan dalam industri kejuruteraan mendapati bahawa majikan dalam industri kejuruteraan berpuas hati dengan 
kemahiran teknikal graduan kejuruteraan, namun ada kemahiran penting yang kurang dikuasai graduan kejuruteraan iaitu kemahiran bekerja dalam kumpulan, komunikasi, dan penyelesaian masalah.

Kekurangan dalam kemahiran insaniah juga dilaporkan di kalangan graduan lepasan politeknik dan vokasional. Sebilangan besar lulusan teknikal institusi pengajian tinggi (IPT) didapati tidak memiliki kemahiran insaniah yang diperlukan oleh majikan (Mohamad Sattar Rasul, et al. 2009). Mohamed Rashid (2005) dalam kajiannya ke atas lulusan politeknik mendapati sejumlah $50.5 \%$ lulusan teknikal politeknik menganggur selama hampir sembilan bulan setiap tahun disebabkan oleh masalah kurangnya kemahiran insaniah. Beliau mendapati pelajar lulusan ini lemah dalam kemahiran komunikasi, menulis dan kemahiran komputer.

Selain kemahiran insaniah, faktor demografi seperti jantina, etnik dan jurusan pengajian juga memainkan peranan dalam kejayaan graduan memperoleh pekerjaan. Daripada data perangkaan guna tenaga dan pengangguran dikalangan siswazah dari tahun 1982 hingga 2010 yang dilaksanakan oleh Jabatan Perangkaan Malaysia didapati lebih ramai graduan perempuan menganggur $(3.86 \%$ pada tahun 2009 dan $3.58 \%$ pada tahun $2010)$ berbanding graduan lelaki menganggur $(2.23 \%$ pada tahun 2009 dan $2.38 \%$ pada tahun 2010). Isu lebih ramai graduan perempuan mengganggur menimbulkan tanda tanya, walhal di peringkat persekolahan pencapaian akademik pelajar perempuan adalah jauh lebih baik. Keputusan peperiksaan awam peringkat kebangsaan 1996 hingga 2011 menunjukkan secara keseluruhannya pelajar perempuan mempunyai pencapaian lebih baik berbanding pelajar lelaki dalam hampir semua mata pelajaran Zalizan, et al. (2005). Inisiatif diambil oleh penulis untuk membongkar isu ini dengan menjalankan kajian perbezaan dalam kemahiran insaniah antara jantina.

Kajian ini berkisar pada kajian tindakan penyelidik mengenai kemahiran insaniah pelajar prasiswazah IPT pada pandangan majikan latihan industri. Kajian ini bertujuan untuk mengenal pasti komponen kemahiran insaniah yang kurang dikuasai oleh pelajar supaya boleh dititikberatkan oleh pihak berwajib. Ia dimulai dengan sorotan literatur berkaitan kemahiran insaniah dan kepentingannya di alam pekerjaan. Seterusnya, pemerincian mengenai kemahiran insaniah pelajar dan diikuti pula dengan mengenal pasti perbezaan kemahiran insaniah antara jantina dan antara pelajar tahun 2009 dan 2011. Kertas ini diakhiri dengan perbincangan dan kesimpulan.

\subsection{DEFINASI KEMAHIRAN INSANIAH}

Istilah yang digunakan untuk merujuk kepada kemahiran insaniah berbeza antara negara. Menurut Clayton, et al. (2003), Australia merujuk kemahiran insaniah sebagai 'key competencies', 'soft skills', atau 'employability skills', British pula menggunakan istilah 'key skills' atau 'core skills', manakala Amerika mengguna pakai istilah 'necessary skills' atau 'employability skills'. Kebanyakan istilah tersebut memberi tumpuan ke atas tajuk yang berkaitan dengan gambaran personal, sikap, tabiat, dan juga tingkah laku. Kemahiran generik ataupun kemahiran insaniah merupakan satu set kemahiran yang bertujuan untuk melengkapkan pembentukan insan supaya seimbang serta harmoni dari segi intelek, rohani, emosi dan fizikal, berasaskan pegangan teguh dan kepercayaan kepada Tuhan. Kebanyakannya berkait dengan kemahiran seperti kepimpinan, kerjasama berpasukan, komunikasi dan pembelajaran berterusan.

Terdapat minat yang semakin meningkat dalam penerapan kemahiran insaniah dalam sistem pendidikan. Pelan transformasi kerajaan (Ringkasan Eksekutif Program Transformasi Kerajaan, 2010) menitik beratkan modal insan yang dapat merealisasikan wawasan 2020. Pelan Induk Pendidikan 2006-2010 (2006) menyatakan peranan pendidikan sangat penting dalam usaha membangunkan modal insan yang mempunyai jati diri yang kukuh, berketerampilan, berkeperibadian mulia, berpengetahuan dan berkemahiran tinggi bagi mengisi keperluan negara maju 2020. Modal insan yang dihasilkan perlu mampu untuk berfikir secara kritis dan kreatif, berkemahiran menyelesaikan masalah, berkeupayaan mencipta peluang-peluang baru, mempunyai ketahanan serta kebolehan untuk berhadapan dengan persekitaran dunia global yang sering berubah-ubah. Justeru Pelan Induk Pendidikan 2006-2010 (2006) meletak piawai (standard) bagi semua kurikulum dalam pendidikan tinggi di Malaysia harus mempunyai reka bentuk yang menerapkan kemahiran insaniah yang meliputi, iaitu (i) kemahiran berfikir, bertindak, mengadaptasi, menyelesai masalah dan membuat keputusan, (ii) kemahiran interpersonal dan berkomunikasi, (iii) kemahiran teknologi maklumat, multimedia dan kemahiran pengurusan maklumat, (iv) kemahiran kepimpinan, dan (v) kemahiran keusahawanan.

\subsection{OBJEKTIF KAJIAN}

Kajian ini bertujuan untuk mendapat maklum balas majikan terhadap kemahiran insaniah pelajar Fakulti Teknologi dan Sains Maklumat (FTSM) yang mengikuti latihan industri di syarikat mereka. Di samping itu, kajian ini juga mengenal pasti komponen kemahiran insaniah yang menjadi pembeza efektif dalam menerangkan perbezaan jantina. Persoalan kajian yang di bina adalah:

(1) Apakah komponen kemahiran insaniah yang telah dikuasai dan yang belum dikuasai oleh pelajar?

(2) Adakah kemahiran insaniah pelajar tahun 2011 berbeza dengan pelajar tahun 2009?

(3) Adakah terdapat perbezaan bererti antara kemahiran insaniah pelajar lelaki dan perempuan?

\subsection{METODOLOGI KAJIAN}

Latihan industri di FTSM merupakan kursus wajib (12 unit) dijalani oleh setiap pelajar selama 20 minggu pada semester pertama tahun akhir pengajian. Di akhir latihan industri, prestasi pelajar dinilai oleh penyelia syarikat melalui satu set borang penilaian. Pada tahun 2011, seramai 194 pelajar FTSM menjalani latihan industri di 106 syarikat. Kajian ini menganalisis borang penilaian yang diisi oleh penyelia syarikat pada tahun 2011. Sebanyak 165 borang penilaian berjaya dianalisis, borang penilaian selebihnya tidak dapat dianalisis kerana hilang, rosak ataupun tidak jelas.

Item dalam borang penilaian penyelia syarikat yang dianalisis oleh kajian ini adalah instrumen kemahiran insaniah yang diperoleh daripada Hairulliza \& Noraidah (2009). Instrumen kemahiran insaniah dalam borang penilaian penyelia syarikat mengandungi 21 item yang terdiri daripada enam elemen. Elemen tersebut adalah tanggungjawab sosial (3 item), profesionalisme (6 item), komunikasi (4 item), kerja berpasukan (3 item), penyelesaian masalah (2 item) dan kemahiran ICT (3 item). Elemen tanggungjawab sosial diukur melalui item tanggungjawab diri dan organisasi, mematuhi prosedur dan polisi, dan bertoleransi dengan pelbagai budaya. Elemen profesionalisme diukur melalui item penampilan dan pakaian, integriti dan amanah, menerima teguran, mengurus masa, perwatakan, dan menghormati pandangan. Elemen komunikasi dinilai melalui kebolehan lisan dan penulisan dalam Bahasa Melayu dan Inggeris. 
Kebolehan kerja berpasukan dinilai melalui kerjasama dalam pasukan, toleransi dalam pasukan, dan sumbangan dalam pasukan. Elemen penyelesaian masalah dinilai melalui kebolehan mengenal pasti dan menganalisis masalah dan kebolehan membuat keputusan. Akhir sekali, elemen kemahiran ICT dinilai melalui penggunaan perkakasan dan perisian ICT di samping beretika. Instrumen ini telah diuji dan nilai pekali kebolehpercayaan yang diperoleh adalah 0.959. Setiap item kemahiran insaniah mengkehendaki penyelia menilai skor pelajar dalam skala Likert satu hingga lima. Skala ini menggambarkan tahap prestasi pelajar dalam item yang diukur, 1=sangat lemah, 2=lemah, 3=memuaskan, 4=baik, 5=sangat baik.

Data yang dikumpul melalui borang penilaian penyelia syarikat dianalisis secara deskriptif dan inferensi menggunakan ujian-t. Analisis deskriptif dijalankan untuk mengenal pasti tahap penguasaan kemahiran insaniah pelajar. Manakala ujian-t digunakan untuk membandingkan tahap penguasaan kemahiran insaniah pelajar latihan industri tahun 2009 dan 2011. Ujian-t juga dijalankan untuk menguji kewujudan perbezaan kemahiran insaniah antara jantina. Hasil kajian ini telah berjaya mengenal pasti dan memenuhi objektif dan seterusnya mencapai matlamat kajian yang dikemukakan.

\subsection{DAPATAN KAJIAN}

\subsection{Analisis Tahap Penguasaan Kemahiran Insaniah}

Penentuan tahap penguasaan kemahiran insaniah dalam kajian ini berdasarkan peraturan umum oleh Nugent, Sieppert \& Hudsan (2001) yang menyatakan bahawa skor-skor ini boleh digunakan untuk menggambarkan satu magnitud yang bersifat kontinum. Skor yang tinggi menunjukkan magnitud yang besar, manakala skor yang rendah menunjukkan magnitud yang kecil. Dalam kajian ini, skor 4 hingga 5 menunjukkan tahap kemahiran yang tinggi, manakala skor 3 hingga 4 menunjukkan tahap yang sederhana.

Analisis statistik deskriptif iaitu min digunakan untuk menjawab persoalan kajian 1. Berdasarkan Jadual 1, analisis min setiap elemen kemahiran insaniah, menunjukkan min bagi elemen kerja berpasukan $(\min =4.51)$, profesionalisme $(\min =4.48)$, tanggungjawab sosial $(\min =4.47)$, dan kemahiran ICT $(\min =4.32)$ didapati berada di tahap tinggi. Ini menunjukkan pelajar mempunyai kemahiran bekerja dalam pasukan, profesionalisme dalam kerjaya, bertanggungjawab dan mempunyai kemahiran teknikal ICT yang baik. Walau bagaimanapun, min bagi elemen komunikasi $(\min =3.99)$ dan penyelesaian masalah $(\min =3.93)$ didapati berada pada tahap sederhana. Ini menunjukkan pelajar masih belum menguasai kemahiran komunikasi dan kemahiran penyelesaian masalah walaupun mereka telah berada di tahun akhir pengajian.

Seterusnya, analisis setiap item kemahiran insaniah dilakukan untuk mengetahui secara terperinci item kemahiran insaniah yang berjaya dikuasai dan yang belum dikuasai oleh pelajar. Jadual 1 menunjukkan min bagi item kemahiran insaniah yang mencapai skor yang tinggi adalah seperti berikut: berpakaian santun $(\min =4.59)$, perwatakan baik $(\min =4.59)$, menghormati pandangan $(\mathrm{min}=4.53)$, menghormati pandangan pasukan $(\min =4.55)$, kebolehan kerja berpasukan $(\min =4.52)$, bertoleransi $(\min =4.50)$, mematuhi prosedur $(\min =4.49)$, integriti $(\min =4.45)$, sedia membantu $(\mathrm{min}=4.45)$, bertanggungjawab $(\min =4.44)$, menerima teguran $(\mathrm{min}=4.40)$, mahir guna perkakasan ICT $(\min =4.37)$, beretika guna ICT $(4.36)$, boleh mengurus masa $(\mathrm{min}=4.33)$, mahir guna perisian ICT $(\min =4.29)$, boleh menyampaikan idea secara lisan $(\min =4.17)$ dan bertulis $(\min =4.21)$ dalam Bahasa Melayu. Min yang tinggi ini menunjukkan bahawa pelajar jurusan IT adalah profesionalisme dalam kerjaya, boleh bekerja dalam pasukan, pandai mengurus masa dan boleh berkomunikasi dalam Bahasa Melayu. Selain itu, majikan juga berpuas hati dengan kemahiran teknikal (perkakasan dan perisian ICT) pelajar.

Walaupun majikan memberikan skor yang tinggi untuk 17 item kemahiran insaniah, namun ada 4 item kemahiran insaniah yang diberi skor yang sederhana. Jadual 1 menunjukkan min bagi item kemahiran insaniah yang mencapai skor yang sederhana adalah seperti berikut: boleh menyampaikan idea secara lisan $(\min =3.96)$ dan bertulis $(\min =4.04)$ dalam Bahasa Inggeris, kebolehan menganalisis masalah $(\min =3.98)$, dan menjana keputusan $(\min =3.89)$. Min yang sederhana ini menunjukkan bahawa pelajar IT kurang menguasai dalam kemahiran menyelesaikan masalah dan kemahiran komunikasi dalam Bahasa Inggeris. Hasil dapatan ini selaras dengan kajian oleh Kementerian Pengajian Tinggi pada tahun 2009 yang mendapati antara faktor utama graduan gagal mendapat pekerjaan ialah kurang kemahiran berkomunikasi serta kelemahan bertutur dan menulis dalam Bahasa Inggeris (BERNAMA, 2010; IPPTN, 2009; IPPTN, 2004). Malaysia terdiri daripada pelbagai etnik dan etnik Cina menguasai bidang perniagaan. Syarikat multinasional juga banyak terdapat di Malaysia. Justeru ketidakbolehan berkomunikasi dalam Bahasa Inggeris dapat menjejaskan peluang kerjaya pelajar.

\subsection{Perbezaan Tahap Kemahiran Insaniah Pelajar Dahulu dan Sekarang}

Dalam menjawab persoalan kajian 2, perbandingan min tahap penguasaan kemahiran insaniah pelajar latihan industri FTSM tahun 2011 dengan pelajar latihan industri FTSM tahun 2009 dilakukan. Tahap penguasaan kemahiran insaniah pelajar tahun 2009 diperoleh daripada Hairulliza \& Noraidah (2009) yang menganalisis sebanyak 191 borang penilaian yang diisi oleh penyelia syarikat pada tahun 2009. Analisis ujian-t digunakan untuk meneliti perbezaan yang bererti di antara item kemahiran insaniah dengan jarak masa pada aras .05.

Hasil analisis ini dapat menjelaskan bahawa pelajar latihan industri FTSM tahun 2011 mempunyai tahap penguasaan kemahiran insaniah pada tahap yang tidak berbeza dengan dua tahun sebelumnya. Ujian-t melalui Jadual 1 menunjukkan bahawa daripada 21 item kemahiran insaniah yang diuji, hanya kebolehan lisan Bahasa Melayu menunjukkan perbezaan yang bererti $(t>$ 1.960). Perbandingan min 20 item kemahiran insaniah yang lain tidak menunjukkan perbezaan yang bererti. Ini bermakna pelajar FTSM tahun 2009 dan 2011 mempunyai tahap penguasaan kemahiran insaniah yang tidak berbeza. Justeru pihak pengurusan FTSM perlu bertindak untuk meningkatkan tahap penguasaan kemahiran menyelesaikan masalah dan komunikasi dalam Bahasa Inggeris yang dibuktikan berada hanya pada tahap sederhana bagi pelajar latihan industri tahun 2009 dan 2011. 
Jadual 1 Ujian-t signifikan pada aras .05 kemahiran insaniah di antara pelajar 2009 dan 2011

\begin{tabular}{|c|c|c|c|c|c|c|}
\hline \multirow[b]{2}{*}{ Elemen \& Item Kemahiran Insaniah } & \multicolumn{2}{|c|}{ Pelajar 2009} & \multicolumn{2}{|c|}{ Pelajar 2011} & \multirow[b]{2}{*}{$\mathrm{t}$} & \multirow[b]{2}{*}{ Nilai- $p$} \\
\hline & Min & Sisihan piawai & Min & Sisihan piawai & & \\
\hline Tanggungjawab sosial & 4.56 & .59 & 4.47 & .64 & 1.389 & $p>0.05$ \\
\hline Bertanggungjawab & 4.54 & .68 & 4.44 & .71 & 1.347 & $p>0.05$ \\
\hline Mematuhi prosedur dan polisi & 4.60 & .62 & 4.49 & .66 & 1.596 & $p>0.05$ \\
\hline Bertoleransi pelbagai budaya & 4.54 & .63 & 4.50 & .68 & 0.530 & $p>0.05$ \\
\hline Profesionalisme & 4.56 & .51 & 4.48 & .56 & 1.316 & $p>0.05$ \\
\hline Berpakaian santun & 4.65 & .50 & 4.59 & .59 & 0.904 & $p>0.05$ \\
\hline Integriti dan amanah & 4.53 & .63 & 4.45 & .71 & 1.164 & $p>0.05$ \\
\hline Menerima teguran & 4.50 & .66 & 4.40 & .66 & 1.471 & $p>0.05$ \\
\hline Mengurus masa & 4.39 & .76 & 4.33 & .75 & 0.730 & $p>0.05$ \\
\hline Perwatakan baik & 4.67 & .54 & 4.59 & .65 & 1.253 & $p>0.05$ \\
\hline Menghormati pandangan & 4.62 & .60 & 4.53 & .61 & 1.281 & $p>0.05$ \\
\hline Kerja berpasukan & 4.52 & .60 & 4.51 & .58 & 0.207 & $p>0.05$ \\
\hline Kebolehan kerja berpasukan & 4.50 & .70 & 4.52 & .62 & -0.347 & $p>0.05$ \\
\hline Menghormati pandangan pasukan & 4.56 & .64 & 4.55 & .60 & 0.145 & $p>0.05$ \\
\hline Sedia membantu rakan sepasukan & 4.50 & .67 & 4.45 & .68 & 0.772 & $p>0.05$ \\
\hline Kemahiran ICT & 4.38 & .61 & 4.32 & .60 & 0.943 & $p>0.05$ \\
\hline Mahir guna perkakasan ICT & 4.39 & .69 & 4.37 & .65 & 0.381 & $p>0.05$ \\
\hline Mahir guna perisian ICT & 4.30 & .69 & 4.29 & .67 & 0.266 & $p>0.05$ \\
\hline Guna ICT secara sah dan beretika & 4.45 & .69 & 4.36 & .69 & 1.159 & $p>0.05$ \\
\hline Komunikasi & 4.14 & .63 & 3.99 & .72 & 2.033 & $p<0.05$ \\
\hline Kebolehan lisan Bahasa Melayu & 4.32 & .71 & 4.17 & .67 & 2.093 & $p<0.05$ \\
\hline Kebolehan lisan Bahasa Inggeris & 3.98 & .75 & 3.96 & .68 & 0.271 & $p>0.05$ \\
\hline Kebolehan menulis B. Melayu & 4.28 & .70 & 4.21 & .67 & 1.021 & $p>0.05$ \\
\hline Kebolehan menulis B. Inggeris & 4.00 & .75 & 4.04 & .67 & -0.552 & $p>0.05$ \\
\hline Penyelesaian masalah & 4.00 & .72 & 3.93 & .77 & 0.837 & $p>0.05$ \\
\hline Kenal pasti dan analisis masalah & 4.04 & .76 & 3.98 & .80 & 0.740 & $p>0.05$ \\
\hline Menjana keputusan & 3.96 & .77 & 3.89 & .80 & 0.865 & $p>0.05$ \\
\hline
\end{tabular}

\subsection{Perbezaan Kemahiran Insaniah Berdasarkan Jantina}

Dalam kajian ini, 35.8\% (59 orang) daripada jumlah pelajar yang dinilai oleh penyelia syarikat adalah lelaki dan $64.2 \%$ (106 orang) adalah pelajar perempuan. Ini menunjukkan bahawa pelajar perempuan lebih ramai mengikuti latihan industri pada tahun 2011. Kajian ini mendapati tahap penguasaan kemahiran insaniah pelajar lelaki dan perempuan semasa menjalani latihan industri adalah tidak berbeza. Ujian-t dalam Jadual 2 menunjukkan tidak terdapat perbezaan yang bererti tahap penguasaan kemahiran insaniah antara pelajar lelaki dengan pelajar perempuan $(p=.374)$. Hasil dapatan ini selaras dengan kajian oleh Megat Aman Zahiri, et al. (2007) terhadap 315 guru pelatih di Fakulti Pendidikan, Universiti Teknologi Malaysia di mana dalam kajiannya mendapati tiada perbezaan yang bererti $(p=.128)$ pada tahap kemahiran insaniah antara guru pelatih lelaki dan perempuan.

Analisis terperinci setiap item kemahiran insaniah melalui ujian-t di Jadual 2 menunjukkan bahawa pelajar lelaki dan perempuan mempunyai tahap penguasaan kemahiran komunikasi, kemahiran guna perisian, kemahiran penyelesaian masalah dan kemahiran kerja berpasukan yang sama. Malahan tahap bertanggungjawab, bertoleransi, integriti, mematuhi prosedur, perwatakan baik, dan berpakaian santun juga tidak menunjukkan perbezaan bererti antara jantina. Namun begitu, ujian-t melalui Jadual 2 menunjukkan bahawa terdapat perbezaan bererti $(p<$ .10) pada tahap kemahiran guna perkakasan ICT pelajar lelaki $(\min =4.49$, s.p $=.70)$ dan perempuan $(\min =4.30$, s.p=.66). Ini bermakna pelajar lelaki lebih mahir mengguna perkakasan ICT berbanding perempuan.

Pelajar perempuan pula didapati lebih mudah menerima teguran, lebih menghormati pandangan orang lain dan lebih pandai mengurus masa berbanding pelajar lelaki. Hal ini dibuktikan melalui ujian-t dalam Jadual 2 di mana terdapat perbezaan yang bererti $(p<.05)$ antara kebolehan menerima teguran pelajar lelaki $(\mathrm{min}=4.24$, $\mathrm{s.p}=.70)$ berbanding dengan perempuan $(\min =4.50, \mathrm{~s} . \mathrm{p}=.60)$. Pelajar lelaki $\quad(\min =4.41$, s.p=.67) didapati kurang berkebolehan dalam menghormati pandangan berbanding dengan perempuan ( $\min =4.60$, s.p=.56). Kemahiran mengurus masa juga menunjukkan perbezaan bererti $(p<.10)$ di mana tahap kemahiran mengurus masa pelajar lelaki $(\min =4.19$, s.p $=.84)$ juga didapati lebih rendah berbanding perempuan $(\min =4.42$, s.p=.69). Hasil dapatan ini selaras dengan kajian oleh Wan Zah Wan Ali, et al. (2008) terhadap 3025 pelajar universiti di Malaysia di mana dalam kajiannya didapati terdapat perbezaan yang bererti $(p<.01)$ antara pengurusan masa pelajar lelaki $(\min =2.65$, s.p $=.36)$ berbanding dengan pelajar perempuan $(\min =2.69$, s.p $=.33)$. 
Jadual 2 Ujian-t kemahiran insaniah berdasarkan jantina

\begin{tabular}{|c|c|c|c|c|c|c|c|}
\hline Item kemahiran insaniah & Jantina & $\mathrm{N}$ & Mean & Std. Deviation & $\mathrm{df}$ & $\mathrm{t}$ & Sig. \\
\hline \multirow[t]{2}{*}{ Kemahiran insaniah } & Lelaki & 55 & 4.28 & .52 & 163 & -.891 & .374 \\
\hline & Perempuan & 100 & 4.36 & .50 & & & \\
\hline \multirow{2}{*}{ Bertanggungjawab } & Lelaki & 59 & 4.41 & .70 & 163 & -.480 & .632 \\
\hline & Perempuan & 106 & 4.46 & .72 & & & \\
\hline \multirow{2}{*}{ Mematuhi prosedur } & Lelaki & 59 & 4.42 & .70 & 163 & -.977 & .330 \\
\hline & Perempuan & 106 & 4.53 & .64 & & & \\
\hline \multirow{2}{*}{ Bertoleransi } & Lelaki & 59 & 4.47 & .70 & 162 & -.359 & .720 \\
\hline & Perempuan & 105 & 4.51 & .67 & & & \\
\hline \multirow{2}{*}{ Berpakaian santun } & Lelaki & 59 & 4.56 & .62 & 163 & -.558 & .578 \\
\hline & Perempuan & 106 & 4.61 & .58 & & & \\
\hline \multirow{2}{*}{ Integriti } & Lelaki & 59 & 4.34 & .78 & 163 & -1.482 & .140 \\
\hline & Perempuan & 106 & 4.51 & .67 & & & \\
\hline \multirow{2}{*}{ Menerima teguran } & Lelaki & 59 & 4.24 & .70 & 163 & -2.394 & .018 \\
\hline & Perempuan & 106 & 4.49 & .62 & & & \\
\hline \multirow{2}{*}{ Mengurus masa } & Lelaki & 59 & 4.19 & .84 & 163 & -1.887 & .061 \\
\hline & Perempuan & 106 & 4.42 & .69 & & & \\
\hline \multirow{2}{*}{ Perwatakan baik } & Lelaki & 59 & 4.51 & .75 & 98. & -1.090 & .278 \\
\hline & Perempuan & 106 & 4.63 & .59 & & & \\
\hline \multirow{2}{*}{ Menghormati pandangan } & Lelaki & 59 & 4.41 & .67 & 103 & -1.908 & .059 \\
\hline & Perempuan & 106 & 4.60 & .56 & & & \\
\hline \multirow{2}{*}{ Kebolehan lisan Bahasa Melayu } & Lelaki & 56 & 4.20 & .72 & 156 & .354 & .724 \\
\hline & Perempuan & 102 & 4.16 & .64 & & & \\
\hline \multirow{2}{*}{ Kebolehan lisan Bahasa Inggeris } & Lelaki & 59 & 3.92 & .75 & 162 & -.677 & .499 \\
\hline & Perempuan & 105 & 3.99 & .64 & & & \\
\hline \multirow{2}{*}{ Kebolehan menulis B. Melayu } & Lelaki & 56 & 4.25 & .67 & 156 & .572 & .568 \\
\hline & Perempuan & 102 & 4.19 & .67 & & & \\
\hline \multirow{2}{*}{ Kebolehan menulis B. Inggeris } & Lelaki & 59 & 4.02 & .71 & 162 & -.279 & .780 \\
\hline & Perempuan & 105 & 4.05 & .66 & & & \\
\hline \multirow{2}{*}{ Kebolehan kerja berpasukan } & Lelaki & 59 & 4.51 & .63 & 163 & -.196 & .845 \\
\hline & Perempuan & 106 & 4.53 & .62 & & & \\
\hline \multirow{2}{*}{ Menghormati pandangan pasukan } & Lelaki & 59 & 4.51 & .63 & 163 & -.590 & .556 \\
\hline & Perempuan & 106 & 4.57 & .59 & & & \\
\hline \multirow{2}{*}{ Sedia membantu } & Lelaki & 59 & 4.42 & .62 & 163 & -.360 & .719 \\
\hline & Perempuan & 106 & 4.46 & .68 & & & \\
\hline \multirow{2}{*}{ Kenal pasti dan analisis masalah } & Lelaki & 59 & 3.95 & .84 & 163 & -.319 & .750 \\
\hline & Perempuan & 106 & 4.00 & .77 & & & \\
\hline \multirow{2}{*}{ Menjana keputusan } & Lelaki & 59 & 3.85 & .81 & 163 & -.522 & .603 \\
\hline & Perempuan & 106 & 3.92 & .79 & & & \\
\hline \multirow{2}{*}{ Mahir guna perkakasan ICT } & Lelaki & 59 & 4.49 & .60 & 162 & 1.882 & .062 \\
\hline & Perempuan & 105 & 4.30 & .66 & & & \\
\hline \multirow{2}{*}{ Mahir guna perisian ICT } & Lelaki & 59 & 4.29 & .67 & 163 & .047 & .963 \\
\hline & Perempuan & 106 & 4.28 & .67 & & & \\
\hline \multirow{2}{*}{ Beretika guna ICT } & Lelaki & 58 & 4.45 & .63 & 162 & 1.216 & .226 \\
\hline & Perempuan & 106 & 4.31 & .72 & & & \\
\hline
\end{tabular}

\subsection{PERBINCANGAN DAN CADANGAN}

Tahap penguasaan kemahiran insaniah pelajar latihan industri tahun 2011 dan 2009 adalah pada tahap tinggi. Menurut majikan, pelajar santun dalam berpakaian, mempunyai perwatakan baik, menghormati pandangan orang lain, boleh bekerja dalam pasukan, bertoleransi, mematuhi prosedur, integriti, sedia membantu, bertanggungjawab, boleh menerima teguran, mahir dalam penggunaan perkakasan dan perisian ICT, pandai mengurus masa dan boleh berkomunikasi dalam Bahasa Melayu.

Namun begitu, kemahiran menyelesaikan masalah dan komunikasi dalam Bahasa Inggeris pelajar latihan industri tahun 2011 dan 2009 berada pada tahap sederhana. Kemahiran komunikasi melibatkan komunikasi yang berkesan dalam Bahasa Melayu dan Bahasa Inggeris. Komen daripada majikan adalah pelajar kurang berkeyakinan untuk menyampaikan idea dan pandangan mereka sendiri dan mempersembahkan maklumat dengan jelas kepada pihak majikan di tempat mereka menjalani latihan industri. Justeru kemahiran komunikasi dan kemahiran penyelesaian masalah adalah elemen kemahiran insaniah yang perlu diberi lebih penekanan dalam reka bentuk kurikulum terutamanya kepada pihak FTSM di mana kajian ini dilaksanakan.

Kemahiran berfikir dan kemahiran menyelesaikan masalah melibatkan kebolehan berfikir secara kritis, kreatif, inovatif, analitis, serta kebolehan mengaplikasikan pemahaman dan pengetahuan kepada masalah baru dan berlainan. Pemikiran kritis dan kreatif adalah penting kepada pelajar terutamanya pelajar FTSM kerana tuntutan kerja dalam bidang berkaitan aplikasi ICT banyak melibatkan pemikiran kritikal, mendapatkan, menganalisis dan menilai maklumat, membuat perbandingan, menyediakan penyelesaian dan menimbangkan kesan dari pelbagai konteks. Oleh itu, keupayaan pelajar untuk mengenal pasti dan menyelesaikan masalah dan membuat keputusan perlu diambil perhatian oleh pihak pengurusan dalam pembangunan reka bentuk kurikulum.

Secara keseluruhan, tahap penguasaan kemahiran insaniah pelajar antara jantina adalah tidak berbeza. Pelajar lelaki dan perempuan mempunyai tahap penguasaan kemahiran komunikasi, kemahiran guna perisian, kemahiran penyelesaian masalah dan kemahiran kerja berpasukan yang tidak berbeza. Pelajar lelaki dan perempuan juga mempunyai tahap bertanggungjawab, 
bertoleransi, integriti, mematuhi prosedur, perwatakan baik, dan berpakaian santun yang tidak berbeza. Namun, pelajar perempuan didapati lebih mudah menerima teguran dan lebih menghormati pandangan orang lain. Justeru untuk mendisiplinkan lelaki adalah dengan menyenaraikannya dalam prosedur kerana lelaki didapati patuh pada prosedur. Kurangkan amalan menegur lelaki kerana lelaki didapati payah menerima teguran dan kurang menghormati pandangan orang lain.

Berkaitan dengan kemahiran pelajar perempuan yang lebih pandai dalam mengurus masa, dapatan ini selaras dengan dapatan kajian oleh Wan Zah Wan Ali, et al. (2008) dan Misra \& McKean (2000) yang mendapati bahawa pelajar perempuan lebih cekap dalam mengurus masa berbanding pelajar lelaki. Menurut kajian Trueman \& Hartley (1996), pelajar perempuan yang lebih matang memiliki kemahiran pengurusan masa yang lebih baik daripada pelajar lelaki malah berupaya mengurangkan tekanan belajar dan kebimbangan.

Berhubung dengan kemahiran dalam mengguna perkakasan ICT pelajar lelaki yang didapati lebih baik berbanding perempuan, dapatan ini telah menyokong kajian oleh Tech \& Lai (2011), Atan, et al. (2002) dan Lee (1997) yang mendapati bahawa lelaki lebih mahir dalam mengguna perkakasan komputer dan membaiki komputer. Walaupun, lelaki lebih berkemahiran mengguna perkakasan komputer, kajian ini mendapati kemahiran mengguna perisian antara jantina adalah tidak berbeza. Dapatan ini selaras dengan dapatan kajian oleh Tech \& Lai (2011) yang mendapati bahawa tiada perbezaan bererti dalam kemahiran mengguna perisian ICT antara jantina. Malah dapatan ini selari dengan kajian oleh Kirkpatrick \& Cuban (1998) yang mendapati bahawa pendedahan terhadap penggunaan perisian dapat merapatkan jurang perbezaan kemahiran mengguna perisian antara jantina. Pelajar FTSM yang telah didedahkan dengan pelbagai perisian membolehkan pelajar perempuan meningkatkan kemahiran mengguna perisian setanding dengan lelaki. Kaedah yang sama mungkin boleh digunakan untuk mengatasi masalah lebih ramai graduan perempuan menganggur berbanding lelaki. Pendedahan mengenai strategi mendapatkan pekerjaan (seperti menulis resume, strategi menghadapi temu duga, dll) mungkin dapat mengurangkan peratusan graduan perempuan yang menganggur. berikut:

Beberapa rumusan dapatan kajian dapat dibuat seperti

(i) Secara keseluruhan, tahap penguasaan kemahiran insaniah pelajar adalah pada tahap tinggi. Majikan berpendapat pelajar latihan industri santun dalam berpakaian, mempunyai perwatakan baik, menghormati pandangan orang lain, boleh bekerja dalam pasukan, bertoleransi, mematuhi prosedur, integriti, sedia membantu, bertanggungjawab, boleh menerima teguran, mahir dalam penggunaan perkakasan dan perisian ICT, pandai mengurus masa dan boleh berkomunikasi dalam Bahasa Melayu.

(ii) Item kemahiran insaniah yang masih kurang dikuasai oleh pelajar adalah kemahiran menyelesaikan masalah dan komunikasi dalam Bahasa Inggeris.

(iii) Tahap penguasaan kemahiran insaniah pelajar latihan industri tahun 2009 dan 2011 adalah tidak berbeza.

(iv) Pelajar lelaki dan perempuan mempunyai tahap penguasaan kemahiran komunikasi, kemahiran guna perisian, kemahiran penyelesaian masalah dan kemahiran kerja berpasukan yang tidak berbeza.

(v) Pelajar lelaki dan perempuan mempunyai tahap bertanggungjawab, bertoleransi, integriti, mematuhi prosedur, perwatakan baik, dan berpakaian santun yang juga tidak berbeza.

(vi) Pelajar lelaki lebih mahir mengguna perkakasan ICT berbanding perempuan. (vii) Pelajar perempuan didapati lebih mudah menerima teguran, lebih menghormati pandangan orang lain dan lebih pandai mengurus masa berbanding lelaki.

\subsection{KESIMPULAN}

Pihak institusi, terutamanya tenaga pengajar perlu memahami dan menerapkan kemahiran insaniah yang sangat dipentingkan oleh industri kini. Berdasarkan dapatan kajian, adalah digalakkan agar kemahiran menyelesaikan masalah dan komunikasi dalam Bahasa Inggeris dapat diberi penekanan penting dalam proses pengajaran dan pembelajaran (P\&P) di dalam kelas atau bilik kuliah melalui pelbagai latihan dan aktiviti sejak mula pelajar menjejakkan kaki ke universiti. Walaupun kini ia telah dijadikan kemahiran insaniah yang perlu diterap dalam proses $\mathrm{P} \& \mathrm{P}$, namun perlaksanaan dan keberkesanannya hendaklah dipantau dan diberi perhatian sewajarnya.

Graduan pula seharusnya mempunyai sikap yang positif terhadap kerja dan persekitaran, inovatif dan kreatif. Keupayaan untuk mengharungi cabaran dan mengambil risiko bagi menyahut cabaran juga patut diterapkan kepada pelajar. Bekerjasama antara rakan sekerja dan faham matlamat dan permintaan majikan serta mampu bekerja bersendirian dan menghasilkan kerja yang berkualiti juga merupakan satu keperluan industri.

\section{Penghargaan}

Penulis ingin merakamkan ucapan penghargaan kepada Universiti Kebangsaan Malaysia atas pemberian dana Kajian Tindakan (PTS-2011-046) bagi tujuan pembiayaan kertas kerja ini.

\section{Rujukan}

Atan, H., Azli, N., Rahman, Z. \& Idrus, R. 2002. Computers in Distance Education: Gender Differences in Self Perceived Computer Competencies. Journal of Educational Media. 27(3): 123-135.

Azami Zaharim, Yuzainee Md Yusoff \& Mohd Zaidi Omar. 2009. Employers' Perceptions and Expectation toward Engineering Graduates: A Study Case. Proceedings of the 6th WSEAS International Conference on Engineering Education, Rodos, Greece, July 22-24. ISSN: 1790-2769. ISBN: 978-960-474-100-7. 23-29.

Beard, D., Schwieger, D. \& Surendran, K. 2007. Incorporating Soft Skills into Accounting and MIS Curricula. SIGMIS-CPR'07, April 19-21, St. Louis, Missouri, USA. ACM 978-1-59593-641-7/07/0004. 179-185.

BERNAMA. 2010. Dewan Rakyat: 700 Graduan Menganggur Lebih Tiga Tahun. Pertubuhan Berita Nasional Malaysia. 8 November 2010.

Brown, K. W. 2004. What Employees Look for in Job Applicants. Business Education Forum. 30(7): 7.

Clayton, B., Bloom. K., Meyers D. \& Bateman A. 2003. Accessing and Certifying Generic Skills: What is Happening in Vocational Education and Training? State Arcade, South Australia: National Centre for Vocational Education Research Ltd.

Cox, S. \& D. King. 2006. Skill Sets: An Approach to Embed Employability in Course Design. University of Central England, Birmingham, UK. Jurnal Education and Training. 48(4): 262-274.

Hairulliza Mohamad Judi \& Noraidah Sahari @ Ashaari. 2009. Kemahiran Generik Pelajar Menurut Pandangan Majikan, Kongres Pengajaran dan Pembelajaran UKM 2009. 233-241.

Hassan, B., Mohd Zaidi, O., Zainal, M., Abang Abdullah, A. A., Badrulhisham, A.A, Abdul Hamid, H., Nik Abdullah, N.M., Azmi, H. \& Zaidi, M.R 2007. The Future of Engineering Education in Malaysia. Laporan oleh the Department of Institutions of Higher Education Management, Ministry of Higher Education, Malaysia.

Jabatan Perangkaan Malaysia. 2011. Perangkaan guna tenaga dan pengangguran di kalangan siswazah dari tahun 1982 hingga 2010: http://www.statistics.gov.my/portal/download_Labour/files/BPTMS/PER ANGKAAN_\%20SISWAZAH_2011.pdf. 
Kirkpatrick, H. \& Cuban, L. 1998. What the Research Says about Gender Differences in Access, Use, Attitudes and Achievement with Computers, Educational Technology. 38: 56-61.

Lee, V. E. 1997. Effects of High School Restructuring and Size on Early Gains in Achievement and Engagement. Sociology of Education. 68: 241-70.

Mariana, Y. 2008. Communication in Oral Presentation: A Malaysian Experience. IEEE International Profesional Communication Conference. Article number 4610248.

Megat Aman Zahiri Megat Zakaria, Baharudin Aris, Jamaluddin Harun \& Mohd Zolkifli Abd Hamid. 2007. Hubungan antara Kemahiran Generik dengan Jantina, Pengkhususan dan Pencapaian Guru-Guru Pelatih UTM: Satu Tinjauan. Seminar penyelidikan Pendidikan 2007, pada 5-6 September 2007 di Kuching, Sarawak. Anjuran Institut Pendidikan Batu Lintang, Sarawak dan BPG

Misra, R. dan M. McKean. 2000. College Students' Academic Stress and its Relation to their Anxiety, Time Management, and Leisure Satisfaction. American Journal of Health Studies. 16: 41-45.

Mohamad Sattar Rasul, Md Yusof Ismail, Napsiah Ismail, et al. 2009. Peranan Institusi Pendidikan Teknikal dalam Pemupukan Kemahiran 'Employability' Pelajar. Jurnal Teknologi. 50(E) Jun 2009: 113-127.

Mohamed Rashid Navi Bax \& Mohd Rashahidi Mohamood. 2005. The Year 2004 Polytechnic Convocation Survey. Proceedings of National Seminar The Development of Technology and Technical-Vocational Education and Training in an Era of Globalization: Trend and Issues. Kuala Lumpur.

Institut Penyelidikan Pendidikan Tinggi Negara (IPPTN). 2009. Kurikulum Universiti dan Keperluan untuk Memperoleh Pekerjaan. Monograf Penyelidikan Pendidikan Tinggi. ISBN 978-983-42662-6-4.

Institut Penyelidikan Pendidikan Tinggi Negara (IPPTN). 2004. Masalah Pengangguran di Kalangan Siswazah. Monograf Penyelidikan Pendidikan Tinggi. ISBN 983-41694-0-X.

Nik Azma Wail, Rahmah Ismail \& Ishak Yussof. 2011. Analisis Penentu Perbezaan Upah Mengikut Kemahiran di Malaysia. Jurnal Teknologi. 56 (Sains Sosial), Sept. 2011: 1-22.

Nugent, W., J. Sieppert \& W. Hudson. 2001. Practice Evaluation for the 21st Century. Pacific Grove, CA: Brooks/Cole.

Nurita Juhdi, Ainon Jauhariah \& Shaharudin Yunus. 2007. A Study on Employability Skills of University Graduates. The Business Wallpaper. 2(1)
Pelan Induk Pendidikan 2006-2010. 2006: http://www.moe.gov.my/

Raybould, J. \& V. Sheedy. 2005. Are Graduates Equipped with the Right Skills in the Employability Stakes? Emerald. Journal of Industrial and Commercial Training. 37(5): 259-263.

Ringkasan Eksekutif Program Transformasi Kerajaan - Pelan Hala Tuju 2010: http://klnportal.kln.gov.my/klnvideo/2010/transformasi.

Rohaila Yusof, Faridah Karim \& Norasmah Othman. 2007. Kesan Strategi Pembelajaran Pengalaman Terhadap Pembangunan Kompetensi: Perspektif Pendidikan Perakaunan. Jurnal Teknologi. 46(E), Jun 2007: 126.

Shahran Yaacub. 2005. Meeting the Employer Needs. Proceedings of National Seminar "The Development of Technology and Technical-Vocational Education and Training in an Era of Globalization: Trend and Issues." Kuala Lumpur.

Syed Hussain. 2005. Meeting The Needs of Employers. Proceedings of National Seminar. The development of Technology and TechnicalVocational Education and Training in an Era of Globalization: Trend and Issues. Kuala Lumpur.

Teck, S.H. \& Y.L. Lai, 2011. An Empirical analysis of Malaysian PreUniversity Students' ICT Competency Gender Differences. Inter. J. Network Mobile Technol. 2: 15-29.

Trueman, M. \& J. Hartley. 1996. A Comparison between the Timemanagement Skills and Academic Performance of Mature and Traditionalentry University Students. Higher Education. 32(2): 199-215.

Wan Zah Wan Ali, Aida Suraya Md. Yunus, Ramlah Hamzah, et al. 2008. Kemahiran Pengurusan Masa Pelajar Universiti Tempatan: Status dan Hubungannya dengan Pencapaian. Jurnal Teknologi. 49(E), Dis. 2008 : 49-64.

Yassin, S., Hasan, F., Amin, W. \& Amiruddin. 2008. Implementation of Generic Skills in the Curriculum. Proceedings of the EDU-COM 2008 International Conference. Sustainability in Higher Education: Directions for Change, Edith Cowan University, Perth Western Australia, 19-21 November 2008: http://ro.ecu.edu.au/ceducom/

Zalizan Mohd Jelas, Saemah Rahman, Roselan Baki \& Jamil Ahmad. (2005). Prestasi Akademik Mengikut Gender. Jurnal Pendidikan. 30(2005): 93 111 